\title{
ACCESSIBILITY OF SELECTED BOUNDARY REGIONS IN SLOVAKIA
}

\author{
DANIEL MICHNIAK \\ Institute of Geography, Slovak Academy of Sciences \\ Štefánikova 49, 81473 Bratislava, Slovakia \\ e-mail: geogmich@savba.sk
}

\begin{abstract}
This paper presents accessibility of selected boundary regions in Slovakia - Orava, and Humenné located near the boundary with Poland, and region Humenné bordering also on Ukraine. The paper discusses effects of transport infrastructure and regional accessibility on the regional development and the role of different barriers in the development of transport infrastructure. Accessibility of selected regions has been studied from two different aspects: public transport accessibility and individual automobile transport accessibility and at three different spatial levels i.e. the accessibility of selected boundary regions from other countries, accessibility of regional centres (Dolný Kubín and Humenné) from other towns in Slovakia, and accessibility of individual municipalities in regions from regional centres.
\end{abstract}

Key words: accessibility, transport infrastructure, public transport, individual automobile transport, boundary regions, Slovakia

\section{INTRODUCTION}

Transport accessibility of a region is considered one of important factors for the regional development. Population as well as economic activities concentrate in regions with good accessibility what finds reflection in increased competitiveness of such core regions. On the other side, there are regions that are distant from important economic centres and referred to as peripheral regions.

Transport accessibility of a territory is positively determined by a quality transport infrastructure. Barriers of different nature (natural, political, economic or cultural, etc.) negatively influence the development of transport infrastructure in a certain territory consequently also its accessibility. In some areas, the joint effects of several barriers hinder the region's overall development. Such areas are situated above all next to the country's boundaries. 
The principal aim of the paper is to assess some accessibility aspects of selected regions situated near the Slovak boundaries. Two regions were selected for such purpose: Orava and Humenné, areas of which are similar (1987 and $\left.1660 \mathrm{~km}^{2}\right)$ and so is the population number (115 and 133 thousand). Region Orava consists of districts Dolný Kubín, Námestovo and Tvrdošín while districts Humenné, Medzilaborce and Snina fall in the region of Humenné. Both regions are situated next to the boundary with Poland and the region of Humenné also borders on Ukraine. The biggest towns as well as centres of these regions are Dolný Kubín and Humenné (population of 20 thousand and 35 thousand respectively).

Accessibility of selected regions has been studied from two different aspects - public transport accessibility and individual automobile transport accessibility and at three different spatial levels - accessibility of selected boundary regions from other countries, accessibility of regional centres (Dolný Kubín and Humenné) from other towns in Slovakia and accessibility of individual municipalities in regions from regional centres.

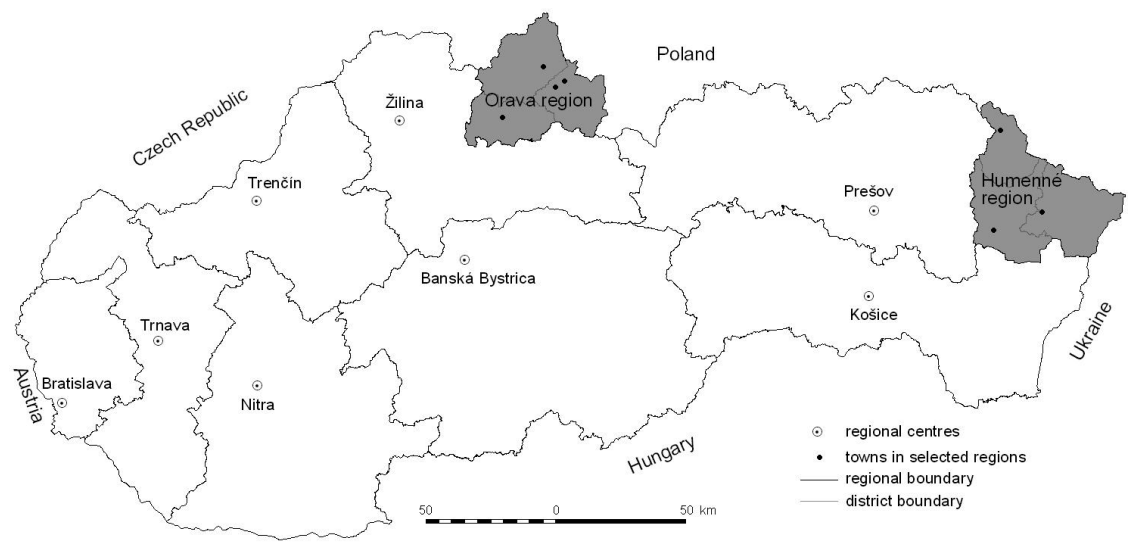

Figure 1. Location of selected regions in the territory of Slovakia

\section{ACCESSIBILITY, TRANSPORT INFRASTRUCTURE AND REGIONAL DEVELOPMENT}

Accessibility is one of the most important and simultaneously most difficult terms to define in human and regional geography. Accessibility can be defined as the ease with which an economic or social activity can be reached using the transport system (OECD 2002). Accessibility is also defined as the measure of the capacity of a location to be reached by, or to reach different locations. Therefore, the capacity and structure of transport infrastructure is a key element in the determination of accessibility (Rodrigue et al. 2009).

The relationship between accessibility, transport infrastructure on the one side and the regional development on the other is often studied. For instance P. Rietveld 
and P. Nijkamp (1992), R. Vickerman (1995), B. J. Linneker, N. A. Spence (1996), R. Vickerman et al. (1999), OECD (2002), L. Tolmáči and F. Križan (2005), M. Marada et al. (2006), Horňák (2006), K. Spiekermann and M. Wegener (2006) point to the significance of transport infrastructure and accessibility for the development of regions. R. Vickerman (1995) reports that it is difficult to identify the precise nature of the relationship between transport infrastructure and regional development.

Transport infrastructure can both positively and negatively impact the regional development. This impact can be direct or indirect, while the direct impact includes increase of employment in construction during the construction of infrastructure, reduction of consumed fuel, time saving or reduced environmental harm (concerning pollution and noise). Indirect impacts are that on the productivity of the regional economy, labour quality, location of companies, behaviour of households or effects on prize of real estates (Marada et al. 2006).

R. Vickerman (1995) discerns two types of impact of infrastructure on regional developments referred to as spatial and non-spatial effects. The non-spatial effect represents the impact of infrastructure on the overall level of economic activity; productivity and competitiveness in economy while the spatial effect takes into account the way that infrastructure can influence regional performance in different localities and regions or within a region.

Missing connections in transport network represent an important barrier for the potential productivity of certain region (Rietveld and Nijkamp 1992). Additional factors that hinder the development of a region include the existence of transport bottlenecks and overstepping of the transport infrastructure capacity.

One of the most spread tools of regional policy, when the intention is to overcome isolation and economic lag behind of a region, is building of transport infrastructure. The result is the change in the level of accessibility above all in terms of time and cost.

However, investments in infrastructure do not automatically lead to an increased economic performance of the region (Vickerman 1995). The new infrastructure is often built between core regions or within them where the demand of transport is highest. Construction of connections between important centres and periphery can lead to an increase of already existing differences in accessibility between regions (Vickerman et al. 1999), because apart from improved accessibility of periphery also that of the core region improves. A possible result is also an increase of regional disparities between the cores and the peripheral regions.

Infrastructure provision is, however, only a proxy for accessibility, which is only a proxy for the transport cost incurred in a region on the assumption that firms will be able to exploit changes in accessibility in increasing competitiveness, leading to increased regional output, increased per capita incomes and hence increased welfare (Vickerman et al. 1999). 


\section{TRANSTPORT INFRASTRUCTURE IN SELECTED REGIONS}

A quality transport infrastructure is the primary condition of a good region's accessibility. In this context the network of motorways and expressways is crucial for the economic and social development of the region.

Neither of the selected regions (Orava and Humenné) is directly connected with the motorway but in future, D1 motorway will pass along the southern edge of the region of Orava. At present, the motorway segment of Ivachnová-Hybe is the nearest. Apart from motorway, an expressway is to cross Orava as well in future. The R3 will link the Hungarian and Polish borders by the Kral'ovany-Dolný Kubín-TrstenáPolish border segment. The part of Oravský Podzámok-Horná Lehota is ready by now and the construction of a bypass next to Trstená (to be finished in 2010) is under way. Construction of either motorway or expressway in the region of Humenné has not been planned yet. The planned motorway from Košice to Ukraine will run approximately $20 \mathrm{~km}$ south of the region and the planned expressway R4 will run approximately $20 \mathrm{~km}$ west of the region.

The region of Orava is crossed by four 1st class roads in total length of about $125.7 \mathrm{~km}$. They include roads connecting Kral'ovany with Dolný Kubín and Ružomberok with Dolný Kubín, while the last quoted continues over Oravský Podzámok to Trstená and the Polish boundary. At Oravský Podzámok, the first class road joins on the mentioned road to Námestovo, Oravská Polhora and further to the Polish boundary.The basic road networks also consist of the 2 nd and 3rd class roads $(90.5 \mathrm{~km}$ and $241 \mathrm{~km}$ respectively).

On the other side, only one 1st class road passes through the region of Humenné from Strážske over Humenné, Snina, Stakčin, Ubla as far as the Ukrainian boundary. Its total length is about $62 \mathrm{~km}$; the total length of 2 nd and 3 rd class roads amounts to $194 \mathrm{~km}$ and $279 \mathrm{~km}$ respectively. The principal road network consists of $2 \mathrm{nd}$ class roads (Hudcovce-Humenné-Medzilaborce-Čertižné-Polish boundary, Medzilaborce-Palota-Polish boundary, Stakčín_Ulič_Ukrainian boundary).

The existing rail network is also important for the accessibility of the territory in question and consequently its development. The hierarchically most important tracks, that form part of pan-European multimodal transport corridors, of course, enjoy a special position within this network.

The principal railway track Bratislava-Žilina-Košice, part of the 4th multimodal transport corridor passes along the edge of the Orava and it is linked to the $65 \mathrm{~km}$ long regional railway track connecting Kral'ovany and Trstená.

A railway track leads from the south to Humenné, particularly between the towns of Strážske and Humenné; it continues to the north to Medzilaborce and further on over the mountain pass (Lupkovský priesmyk) to Poland. It is $62 \mathrm{~km}$ long. The regional track to Stakčín through town of Snina $(27 \mathrm{~km})$ joins on the above-mentioned one at Humenné. The region of Humenné is situated outside the routes of the panEuropean multimodal transport corridors. 
As far as the accessibility of the nearest railway station is concerned (see Michniak 2006), it is better in the region of Humenné because the mean weighted distance from individual municipalities to the nearest railway station is $3.9 \mathrm{~km}$ against the same distance in Orava, which amounts to $11.2 \mathrm{~km}$. The great difference in accessibility of railways is caused above all by the fact that in spite almost $44 \%$ of total Orava's population living in the district of Námestovo, it lacks the railway. The village of Nová Sedlica is the remotest one from the nearest railway station $(36 \mathrm{~km})$ in the region of Humenné; in the region of Orava it is the village Oravská Lesná $(35.5 \mathrm{~km})$.

From the point of view of accessibility of transport infrastructure (Horñák et al. 2008), the region of Humenné is one of those that are distinctly peripheral in terms of transports. Region of Orava is quite differentiated in this sense while the district of Námestovo is conspicuous for its peripheral position; the district Tvrdošín meets some criteria of peripherality while the district of Dolný Kubín is not classified among those that are peripheral to transport networks.

\section{BARRIERS AND THEIR EFFECT ON THE DEVELOPMENT OF TRANSPORT INFRASTRUCTURE AND ACCESSIBILITY}

Development of transport infrastructure in certain territory, as well as accessibility of the territory, are subjects to negative effects of barriers of different types: natural, political, economic, cultural or psychological. Among the most significant barriers are the natural ones, such as the relief (mountain ranges) and waters (rivers, water reservoirs). In case of regions with valuable natural environment, which is also subject of environmental protection, barriers to the development of transport infrastructure are referred to as environmental. Economic barriers to the construction of transport infrastructure dwell above all in high cost. Political barriers gain a special importance in boundary areas. Different political systems or a closed political system in immediate neighbourhood can lead to reluctance to construct of cross-border infrastructure. Construction of infrastructure in a boundary territory, which may become peripheral and not easily accessible, is also often reconsidered. Cultural barriers manifest themselves above all next to the borders of countries with different cultures, using different languages, in scarce interest in cross-border transport and a low demand for construction of transport infrastructure. The combined effect of several types of barriers with negative impact on territory's accessibility and overall development of the region is obvious in some regions. Such regions are normally located near countries' boundaries. A detailed research into development of cross-border links on example of the Slovak-Polish boundary territory was conducted by M. Więckowski (2004).

Mountain barriers existing practically on the entire girt of the region of Orava negatively influence its accessibility. The Tatras, the ranges of Chočské vrchy and Malá Fatra are in the south, Kysucká vrchovina is in the west, and Oravské Beskydy 
in the north-west. The region of Orava is open in the area of the Oravska kotlina Basin with the contiguous Nowotargská kotlina Basin where there is the most important border crossing between Slovakia and Poland (Trstená-Chyżne). The Dam of Orava (finished in 1954) and extensive areas of waterlogged forest located in the Oravská kotlina Basin also constitute a barrier for the development of transport infrastructure.

The quoted physical barriers contain some valuable natural environment subject to protection. Part of the Tatra and Malá Fatra National Parks are in this territory. Apart from that there is the Protected Area of Horná Orava, a portion of the PA of Kysuce and numerous small PAs.

Another example of the barrier effect for accessibility of Orava was flooding of the road between the regions of Orava and Kysuce in time when the dam of Nová Bystrica was under construction in 1983-89. Construction of a new road between Oravská Lesná and Nová Bystrica, which passes through the mountain range, was complicated. The road was only finished in 2008.

Accessibility of the region of Humenné is restricted by the natural barriers namely the mountain ranges of Vihorlatské vrchy in the south, Nízke Beskydy in the north and Bukovské vrchy in the north-east. The region is physically well accessible in the western part over the valleys of the Laborec and Cirocha Rivers. The quoted mountain barriers also contain valuable natural environment subject to protection. There is the National Park of Poloniny and parts of the territories corresponding to the PA of Vihorlat and the PA of Východné Karpaty along with some small PAs.

\section{PUBLIC TRANSPORT ACCESSIBILITY OF SELECTED REGIONS FROM OTHER COUNTRIES}

The transport-peripheral location of regions Orava and Humenné also manifests itself in international public transport.

The region of Orava is directly connected by bus lines to the Czech Republic (Prague, Brno), which serve to citizens commuting from Slovakia to the $\mathrm{CzR}$, students studying in the CzR. On the other side, Czech citizens who find attractive Slovakia's tourist destination also use them (see Michniak 2008). With the exception of the link on the route Prague-Brno-Trenčín—Martin—Dolný Kubín—Námestovo, the rest of them pass only on the edge of the region over the commune of Kral'ovany.

Likewise, the international train connections of the region of Orava with the Czech Republic (Humenné-Žilina-Prague, Košice-Žilina_Prague), Austria and Ukraine (Kiev-Lvov—Košice-Žilina_Bratislava-Vienna), as well as the links on the main railway track of Slovakia pass through Kral'ovany, which is an important junction for Orava where additional links of regional public transport join on.

Apart the quoted connections a direct connection between the Polish town of Zakopane and thermal swimming pools of Oravice and Liptovský Mikuláš also exists 
albeit it only operates during the summer tourist season. International bus connections between Poland and Italy pass through Orava and one of them stops there. However, these connections concentrate on transport to Italy and are not suitable for local transport in the boundary area..

In spite of the fact that the region of Orava borders on Poland, international public transport to Poland is underdeveloped. Both Poland and Slovakia possess their own public transport networks, which lack mutual connection between the boundary municipalities (Suchá Hora-Chocholów, Trstená-Chyżne, Bobrov-Lipnica Wielka, Oravská Polhora-Korbielów, Novot'-Ujsoly). Individual car transport is therefore mostly used although a potential for the establishment of direct transport connections by public transport exists.

The region of Humenné has direct bus connections above all with the Czech Republic (Prague, Brno, Plzeň), followed by those with Great Britain (London), Germany and Netherlands. Some connections to the CzR start at the town of Snina while all international bus connections start or at least stop at the town of Humenné.

Direct international railway connections in the region of Humenné exists between the town of Medzilaborce and the Polish boundary station of Lupków, which only operates during summer school holidays (two trains daily on Friday, Saturday and Sunday). Apart from that a train connection with the CzR (HumennéŽilina-Prague) also exists. There is no connection to Ukraine in spite of the fact of the existing border crossing of Ubla-Malyj Bereznyj. Absence of connections to Ukraine has been caused by the political barrier represented by the boundary between the SR and Ukraine, which is also the boundary of the Schengen Area. Connections with Poland are scarce as well. Before Slovakia joined the Schengen Area, only one border crossing existed here (Palota-Radoszyce). The ridges of the mountain ranges of Nízke Beskydy and Bukovské vrchy in this case represent the most important barrier.

\section{PUBLIC TRANSPORT ACCESSIBILITY OF SELECTED REGIONS FROM OTHER TOWNS IN SLOVAKIA}

One of important indicators of region's accessibility is the accessibility of region's centre from other towns in Slovakia by means of direct transport connections by public transport. V. Székely (2008) researched the direct transport connections between all district towns in Slovakia. In case of selected regions, towns of Dolný Kubín a Humenné are regarded as their centres.

The town of Dolný Kubín is directly connected by busses with 34 towns in Slovakia (see Figure 2), the most numerous connections are with the nearest town of Ružomberok (almost 200 in week) and with other towns in the region Orava: Námestovo, Tvrdošín a Trstená (more than 120 in a week ). They are followed by the centre of the administrative region of Žilina, the Central Slovakian centre of 
Banská Bystrica and the Capital-Bratislava. Dolný Kubín has the direct bus connection with all centres of administrative regions of the country except for Košice.

The town of Dolný Kubín is directly connected by railway only with other towns in the region of Orava: Trstená and Tvrdošín (71 connections in a week). A change is necessary at Kral'ovany situated on the main railway track between BratislavaŽilina-Košice for further railway connections with other towns in Slovakia.

Considering the sum of bus and train connections, the town of Dolný Kubín is best connected with towns of Tvrdošín, Trstená, Námestovo and Ružomberok in terms of public transport while it has a more than 180 connections average (more than 25 connections daily) a week to each of these towns.

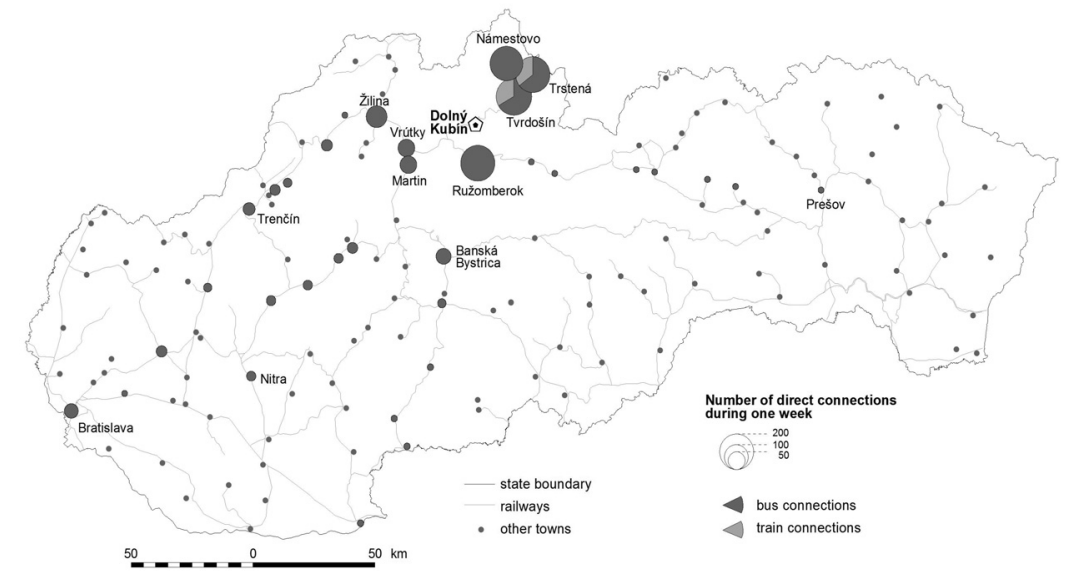

Figure 2. Direct public transport connections of Dolný Kubín town with other towns in Slovakia

The town of Humenné is directly connected by bus with 38 towns in the country. Its best connection is that with the town of Vranov nad Toplou, followed by the surrounding towns: Snina, Strážske, Michalovce, centre of the administrative region Prešov and the principal centre of Eastern Slovakia, Košice. Number of bus lines to the town of Medzilaborce is comparatively low caused by the peripheral position and small population of the town. Apart from these, the direct connection with towns situated on the route to Bratislava, which leads both across the south and north of the country is also important.

The town of Humenné is directly connected with 25 towns via railway. The most intensive direct train connection is with the nearest town of Strážske, situated on the crossroads of railway tracks leading to Humenné (Prešov-Vranov nad ToplouHumenné and Košice-Trebišov-Michalovce-Humenné). Apart from that, there are connections with the towns situated along the main railway tracks crossing Žilina and ending in Bratislava.

Strážske, Snina, Vranov nad Toplou and Michalovce with more than 200 connections a week (30 a day) dominate among the towns connected with Humenné by both 
the bus and train lines. They are followed by Vranov nad Topl'ou, Michalovce, Prešov and Hanušovce nad Topl'ou with more than 100 connections a week (more than 15 connections a day). Humenné is directly connected with all centres of administrative regions (in case of Nitra and Banská Bystrica the only directions is by bus). Humenné in total has direct connections by public transport with 49 towns in Slovakia.

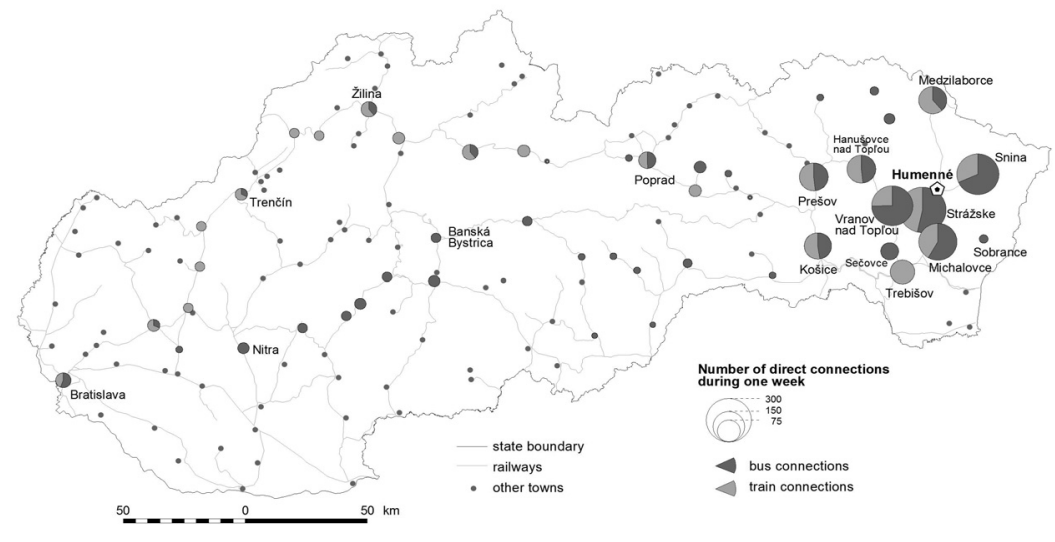

Figure 3. Direct public transport connections of Humenné town with other towns in Slovakia

\section{TRANSPORT ACCESSIBILITY OF CENTRES OF SELECTED REGIONS - PUBLIC TRANSPORT VS. INDIVIDUAL AUTOMOBILE TRANSPORT}

The aim of public transport in a given region is to provide such service that ensures connection of people living in rural areas and periphery with the centre of economic, social, and cultural activities (Surovec 2002). As the towns Dolný Kubín and Humenné are considered centres of regions in question, transport connections of these centres with individual municipalities in the region is also important for inhabitants.

Figure 4 depicts the intensity of direct transport connections between the regional centres and individual municipalities in the two studied regions during a workday (Wednesday). Mainly the municipalities situated along the roads and the municipalities in the direction to $\mathrm{Ru}$ omberok connecting Dolný Kubín with the remaining towns in the region of Orava (Trstená, Tvrdošín and Námestovo) enjoy a favourable accessibility level. Similar situation is in the region of Humenné where the best accessible municipalities are those situated around the centre and along the transport routes connecting the centre with the surrounding towns.

Observing the time accessibility of individual municipalities from centres by public transport (Figure 5), unfavourable level of accessibility of municipalities in Orava is obvious. They are principally municipalities located in remote parts of the north and east of the region lacking direct public transport connections with the centre of the region. Time accessibility is more than $60 \mathrm{~min}$. It represents a significant barrier for everyday mobility of population between these municipalities 

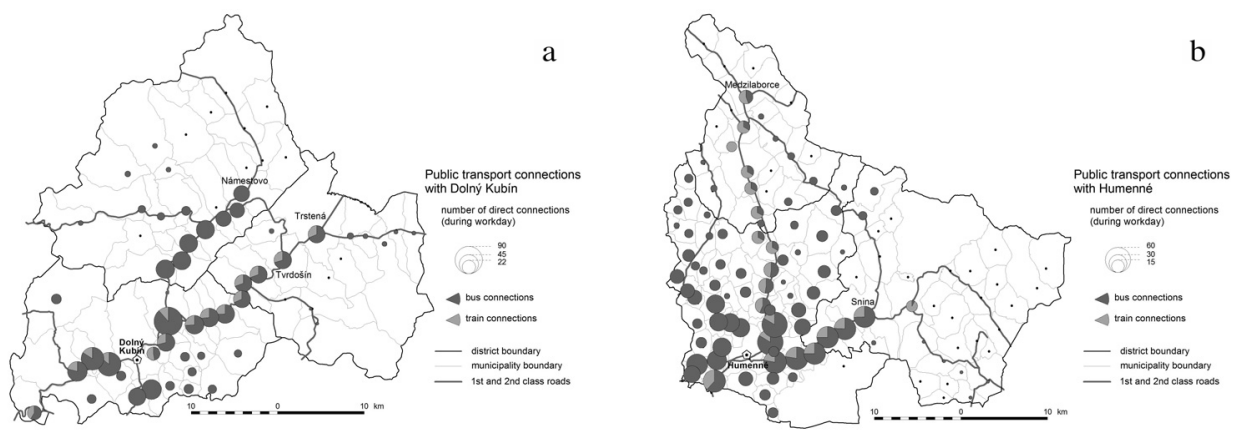

Figure 4. Direct public transport connections of regional centre with individual municipalities in selected region a) Orava region, b) Humenné region
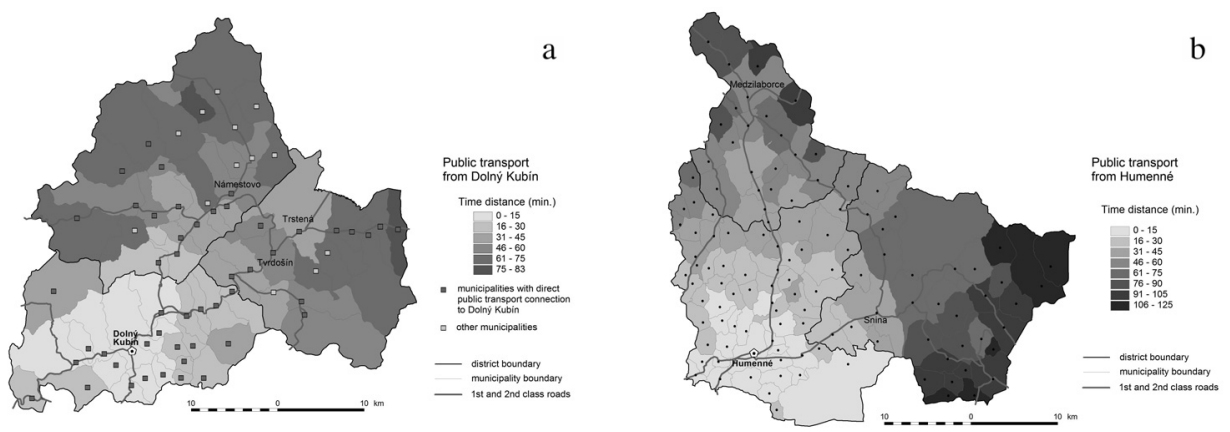

Figure 5. Time accessibility of individual municipalities in selected regions from the regional centre by public transport (minimal travel time) a) Orava region, b) Humenné region
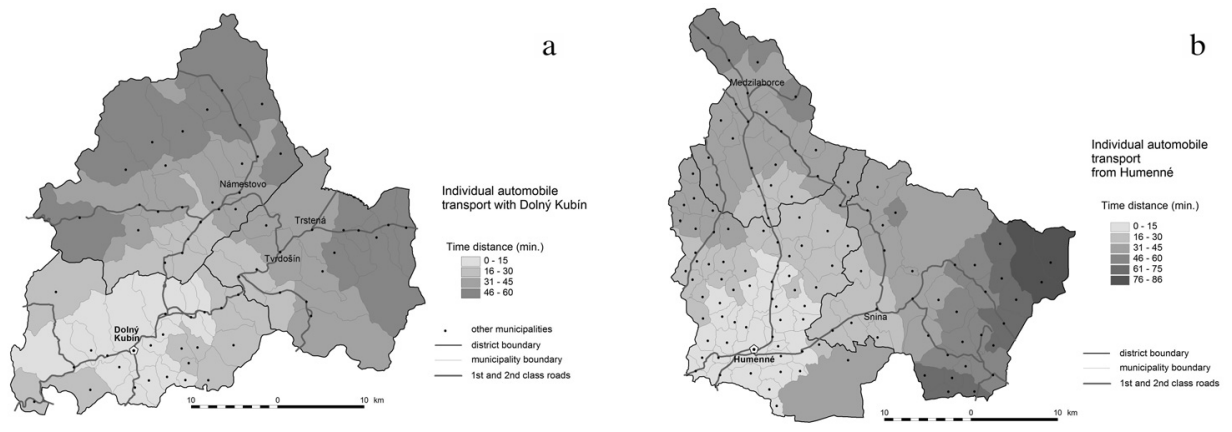

Figure 6. Time accessibility of individual municipalities in selected regions from regional centre by using individual automobile transport (presumed travel time according to route planner-www.viamichelin.co.uk) a) Orava region, b) Humenné region

and Dolný Kubín. On the other side, these municipalities are well connected with the nearest towns (Námestovo, Trstená and Tvrdošín), which are centres on a lower hierarchic level.

Time accessibility of some municipalities in the northern and eastern parts in the region of Humenné compared to Orava is even worse. In case of some munici- 
palities it amounts to $90 \mathrm{~min}$ and more what negatively impacts the socio-economic development of these peripheral municipalities.

The comparison of time accessibility by public transport with that of the individual transport (Figure 6) shows that all municipalities in the region of Orava are accessible from the centre within $60 \mathrm{~min}$. The situation in the region Humenné in this sense is even less favourable as the time accessibility of marginal municipalities from the centre is more than $60 \mathrm{~min}$.

Better time accessibility by car transport is its main advantage in competition with the public transport. This also is the reason why use of individual car transport increases both for commuting to employment centres or to regions attractive as tourist destinations. Personal cars are also intensively used during weekends and day-long stays when the time invested into transports plays a certain role.

\section{CONCLUSIONS}

The aim of this research has been to assess the accessibility of selected boundary regions (Orava and Humenné). Both selected regions can be considered as peripheral from the point of view of higher transport infrastructure. Accessibility of selected regions has been studied on three spatial levels: accessibility from other countries, accessibility of regional centres (Dolný Kubín and Humenné) from other towns in Slovakia and accessibility of individual municipalities in regions from regional centres.

Public transport connections of regional centres with neighbouring countries are insufficient. It is the result of natural barriers and various public transport systems in other countries. Connections between boundary regions in neighbouring countries and that might serve for example to the development of cross-border tourism are missing.

Centres of selected regions enjoy good accessibility from other towns in Slovakia, especially from the nearest towns. Train connections play a more important role in the case of Humenné region. Both centres of selected regions possess direct public transport connections with 8 regional centres in Slovakia (8 administrative units at NUTS II. level) with the exception of connection Dolný Kubín-Košice.

In both selected regions there are peripheral municipalities (in marginal parts of selected regions near natural barriers such as the mountains or the protected areas) with unfavourable time accessibility of regional centres that are better accessible by individual automobile transport. With increasing distance from regional centre, also the difference in time accessibility between public and individual automobile transport increases. Especially in Humenné region there are municipalities with insufficient public transport to the nearest town. Their inhabitants need to have car for their movement to work, to services. It leads to migration of inhabitants to towns. The accessibility of peripheral municipalities by public transport in Orava region is better because of better size structure of rural municipalities that have a higher average number of inhabitants in comparison to the region of Humenné. 
The relative location of individual municipalities in a region to the neighbouring towns plays a very important role for every municipality. Favourable transport accessibility facilitates inhabitants of municipalities commuting to work, schools, and services. Good accessibility on the other side can attract investors that create new workplaces and promote the development of tourism in turn improving the development of the whole region.

\section{ACKNOWLEDGEMENT}

This article has been written under the Project No 2/0096/09 financed by the VEGA Grant Agency and under the Project No WTSL.02.01.00-14-087/08 "Infrastructural and organizational possibilities of improving spatial accessibility as a factor of development of Polish-Slovak tourist regions" co-financed by the EU from the European Regional Development Fund and the State budget for the Programme of cross-border cooperation Poland-Slovak Republic 2007-2013.

\section{REFERENCES}

Horňák, M. (2006), Dopravná infraštruktúra—analýza kontextu regionálneho rozvoja $v$ predtransformačnom období, in: Falt’an L'. (ed.) Regionálna diferenciácia Slovenska v podkladových štúdiách, Sociologický ústav SAV, Bratislava, 392-406.

Horňák, M., Hurbánek, P., Michniak, D., Káčerová, M., Ondoš, S. (2008), Indikátory vybraných aspektov periférnosti na Slovensku, in: Džupinová E. et al. Periférnost' a priestorová polarizácia na území Slovenska, Geo-grafika, Bratislava, 39-108.

Linneker, B. J. and Spence, N. A. (1996), Road transport infrastructure and regional economic development: The regional development effects of the M25 London orbital motorway, Journal of Transport Geography, 4 (2), 77-92.

Marada, M., Květoň, V., Vondráčková P. (2006), Železniční doprava jako faktor regionálního rozvoje, Národohospodář́ský obzor, 4 (4), 51-59.

Michniak, D. (2006), Accessibility of the railway network in Slovakia, Europa XXI, 15, Institute of Geography and Spatial Organization, PAS, Warszawa, 51-61.

Michniak, D. (2008), Priestorové rozmiestnenie priamych dopravných prepojení medzi Slovenskom a Českou republikou, in: Kallabová, E., Smolová, I., Ira, V. et al. Zmèny regionálních struktur České republiky a Slovenské republiky, Ústav geoniky AV ČR, Brno a Univerzita Palackého v Olomouci, 100-105.

OECD (2002), Impact of Transport Infrastructure Investment on Regional Development.

Rietveld, P. Nijkamp, P. (1992), Transport and Regional Development, Research-Memorandum 1992-50, Amsterdam: Vrije Universiteit. 
Rodrigue, J. P., Comtois, C., Slack, B. (2009), The Geography of Transport Systems, Routledge, New York.

Spiekermann, K. and Wegener, M. (2006), The role of transport infrastructure for regional development in South-East Europe, South-East Europe Review for Labour and Social Affairs, 9 (1), 51-61.

Surovec, P. (2002), Verejná osobná doprava v regiónoch, Komunikácie, 1-2, 10-17.

Székely, V. (2008), Priame dopravné prepojenia ako indikátor kvality života: príklad bývalých okresných miest Slovenska, Ludia, geografické prostredie a kva lita života, Geographia Slovaca, 25, Geografický ústav SAV, Bratislava, 63-83.

Tolmáči, L. and Križan, F. (2005), Dostupnost' a regionálny rozvoj, Acta Facultatis Rerum Naturalium Universitatis Comenianae, Geographica, Supplementum, 3, 622-635.

Vickerman, R., Spiekermann, K., Wegener, M. (1999), Accessibility and economic development in Europe, Regional Studies, 33, 1-15.

Vickerman, R. (1995), Location, accessibility and regional development: the appraisal of trans-European networks, Transport Policy, 2 (4), 225-234.

Więckowski, M. (2004), Przyrodnicze uwarunkowania kształtowania się polskosłowackich więzi transgranicznych, Prace Geograficzne, 195, IGiPZ PAN, Warszawa 